\title{
ANALISIS YURIDIS TERHADAP KEWAJIBAN PENCANTUMAN LABEL BERBAHASA INDONESIA PADA BARANG YANG DIPERDAGANGKAN DALAM NEGERI
}

\author{
Bambang Waluyo, Handoyo Prasetyo, Subakdi \\ Fakultas Hukum, Universitas Pembangunan Nasional Veteran Jakarta \\ Jl. RS, Fatmawati, Kota Jakarta Selatan, 12450, Indonesia \\ Email : bambangwaluyo@upnvj.ac.id, handoyoprasetyo@upnvj.ac.id, \\ subakdi@gmail.com
}

\begin{abstract}
Abstrak
Peran perusahaan pembuat produk (produsen) dalam kegiatan perekonomian sangat besar. Produsen akan menentukan produk-produk apa yang akan dibuat dan memastikan produk-produk tersebut akan laku dijual dan terserap pasar dengan baik. Perusahaan akan menggiring konsumen untuk mengkonsumsi produknya. Produsen akan mempromosikan produk yang dibuatnya, baik melalui media konvensional maupun media online atau media sosial seperti youtube, facebook, Instagram dan lain-lain yang saat ini semakin dikenal masyarakat. Sarana penjualan produk dilakukan melalui jalur distribusi barang konvensional, mulai dari produsen dijual ke distributor lalu didistribusikan ke grosir dan terakhir ke pengecer sebelum dijual ke konsumen. Selain itu juga dijual melalui media jual beli online yang saat ini semakin marak dipergunakan masyarakat seiring dengan perkembangan teknologi dan informasi. Dalam proses penjualan produk, produsen diwajibkan untuk senantiasa mentaati norma dan tata cara perdagangan barang yang diatur oleh pemerintah guna melindungan konsumen. Pepatah konsumen adalah raja adalah benar karena tanpa konsumen, produsen niscaya akan tutup karena tidak akan memiliki pendapatan (revenue) sehingga konsumen harus dilayani dengan benar dan jujur. Konsumen berhak atas informasi yang jelas dan lengkap atas barang yang dikonsumsinya agar terhindar dari bahaya dan kerugian fatal akibat mengkonsumsi barang yang salah dan berbahaya. Oleh karena itu diperlukan sanksi yang tegas tapi terukur melalui ketentuan perundang-undangan yang terkait dengan hak-hak perlindungan konsumen dan dengan demikian diharapkan para pelaku usaha tidak semata-mata hanya mengejar keuntungan namun juga menjaga produknya agar aman dan nyaman dikonsumsi oleh konsumen, sebagai bentuk penghargaan dan pengakuan kepada konsumen selaku pihak yang memiliki peran paling penting dalam kegiatan perekonomian.
\end{abstract}

Kata Kunci : Kegiatan Ekonomi, Produk, Produsen, dan Konsumen.

\begin{abstract}
In a series of economic activities, the role of product manufacturing companies (Producer/Manufacturer) is very important. Manufacturer will determine what products will be made and at the same time determine the products which they make will be sold and well absorbed by the market. Producer will lead and begin to attract consumer to buy the product they make. Producer will optimally use of mass media role to promote
\end{abstract}


the products, either through conventional media such as television, newspapers and online media or social media such as YouTube, Facebook, Instagram and others that are currently known by the public. Product sales are carried out through conventional goods distribution channels, ranging from producer sold to distributor then sent to wholesaler and finally to retailer before being sold to consumer. It is also sold through online trading media, which is increasingly used by the public along with developments in technology and information. In the process of selling products, producer are required to make norms and procedures for trade in goods that are regulated by the government to protect consumer. Motto that The Consumer is The King is true, because without consumer, producer will undoubtedly close because they will not have income so consumer must be served correctly and honestly. Consumer have the right to get clear and complete information on the good they consume to avoid danger and fatal losses due to consumption of wrong and dangerous goods. Therefore, it is required a strict and measurable sanctions through statutory provisions related to the rights of customer and thus it is expected that produce are not only aim profit, but also provide safe and comfortable products purchased by consumer as a form of appreciation to consumer as the party who has the most important role in economic activities.

\section{Keywords: Economic Activities, Product, Producer, and Consumer.}

\section{A. PENDAHULUAN}

Perdagangan adalah salah satu bentuk kegiatan perekonomian yang sudah dilakukan manusia sejak jaman dahulu hingga sekarang mengikuti perkembangan sejarah masyarakat. Contohnya adalah perdagangan oleh bangsa China kuno yang dikenal sebagai perjalanan perdagangan jalur sutra (The Silk Road). Jalur sutra adalah sebuah jalur perdagangan melalui Asia yang menghubungkan antara Timur dan Barat dengan dihubungkan oleh pedagang, pengelana, biarawan, prajurit, nomaden dengan menggunakan karavan dan kapal laut, dan menghubungkan Chang'an, Republik Rakyat Tiongkok, dengan Antiokhia, Suriah, dan juga tempat lainnya pada waktu yang bervariasi ${ }^{1}$.

Sektor perdagangan berperan dalam mendukung kelancaran penyaluran arus barang dan jasa, memenuhi kebutuhan pokok rakyat, serta mendorong pembentukan

\footnotetext{
${ }^{1}$ Wikipedia. "Jalur Sutra". https://id.wikipedia.org/wiki/diakses 23 November 2019
} 
harga yang wajar. Pembangunan perdagangan sangat penting dalam upaya mempercepat pertumbuhan ekonomi dan pemerataan, dan memberikan sumbangan yang cukup berarti dalam penciptaan lapangan usaha serta perluasan kesempatan kerja dan peningkatan pendapatan. $^{2}$

Selain sektor perdagangan, kegiatan perekonomian juga mencakup sektor industri yang juga memegang peranan penting bagi pertumbuhan perekonomian di Indonesia, sehingga pemerintah Republik Indonesia saat ini memberikan kemudahan untuk melakukan investasi di Indonesia. Data Badan Pusat Statistik (BPS) menunjukkan, ada tiga sektor yang berkontribusi besar terhadap pertumbuhan ekonomi Indonesia pada kuartal pertama 2019. Ketiga sektor itu adalah industri dengan kontribusi sebesar 20,07\%, lalu perdagangan $12,20 \%$, dan pertanian $12,65 \% .^{3}$

Ditangan sektor industri inilah barang-barang konsumsi atau barang setengah jadi diproduksi oleh pelaku usaha (produsen), yang kemudian didistribusikan oleh distributor dan dijual kepada konsumen oleh pengecer melalui skema jalur distribusi barang sebagaimana diatur dalam Peraturan Menteri Perdagangan Nomor 66 Tahun 2019 tentang Ketentuan Umum Distribusi Barang.

Pelaku usaha berkewajiban untuk melakukan kegiatan usahanya sesuai dengan ketentuan perundang-undangan yang berlaku, termasuk dalam hal ini adalah kewajiban untuk mencantumkan label dalam Bahasa Indonesia pada barang yang diproduksinya. Peraturan Menteri Perdagangan Republik Indonesia Nomor 73/M-DAG/PER/9/2015 tentang Kewajiban Pencantuman Label dalam Bahasa Indonesia pada Barang

\footnotetext{
${ }^{2}$ Bappenas. "Perdagangan". https://www.bappenas.go.id/diakses 23 November 2019

3 Sorta Tobing. "Sektor Industri Masih Penyumbang Terbesar Pertumbuhan Ekonomi". https://katadata.co.id/ diakses 23 November 2019
} 
(“Permendag No. 73 Tahun 2015"), mewajibkan pelaku usaha untuk mencantumkan label dalam Bahasa Indonesia.

Definisi label diuraikan secara lengkap pada Permendag No. 73 Tahun 2015, sebagai berikut :

"Label adalah setiap keterangan mengenai Barang yang berbentuk tulisan, kombinasi gambar dan tulisan, atau bentuk lain yang memuat informasi tentang Barang dan keterangan Pelaku Usaha, serta informasi lainnya yang disertakan pada Barang, dimasukkan ke dalam, ditempelkan/melekat pada Barang, tercatak pada Barang dan/atau merupakan bagian Kemasan Barang”

Dengan demikian label bukan hanya sekedar stiker atau tempelan yang hanya merupakan kewajiban formal pelaku usaha yang tanpa makna sama sekali. Label merupakan sarana komunikasi informasi mengenai suatu barang yang diproduksi oleh pelaku usaha kepada konsumen yang akan mempergunakan produk tersebut. Konsumen berhak untuk mendapatkan hak keamanan, kenyamanan dan keselamatan atas barang yang dibelinya, sebagaimana diatur dalam Undang-undang Nomor 8 Tahun 1999 tentang Perlindungan Konsumen (UU Perlindungan Konsumen).

Dalam undang-undang yang sama juga diatur kewajiban pelaku usaha untuk melayani konsumen secara benar dan jujur serta tidak diskriminatif serta kewajiban untuk memasang label atau membuat penjelasan barang yang memuat nama barang, ukuran, berat/isi bersih atau netto, komposisi, aturan pakai, tanggal pembuatan, akibat sampingan, nama dan alamat pelaku usaha serta keterangan lain untuk penggunaan yang menurut ketentuan harus dipasang/dibuat.

Kewajiban yang diemban oleh Pemerintah Republik Indonesia adalah memberdayakan konsumen untuk memahami hak dan kewajibannya selaku konsumen dan menumbuhkan kesadaran pelaku usaha mengenai pentingnya perlindungan konsumen. Untuk penegakan hukum, Pemerintah Republik Indonesia dibekali dengan 
ketentuan pidana baik yang diatur dalam UU Perlindungan Konsumen maupun undangundang terkait lainnya, sebagaimana akan diuraikan secara rinci dalam penelitian ini.

Dengan demikian ada tiga pihak utama (stake holder) yang diharapkan saling berinteraksi dan masing-masing bertanggung jawab atas perannya (role) yaitu konsumen yang memiliki energi ekonomi untuk membeli barang, pelaku usaha (produsen) yang diharapkan melaksanakan kegiatan usahanya dengan itikad baik dan pemerintah Republik Indonesia yang mengatur norma bisnis sekaligus melaksanakan penindakan hukum dalam hal terjadi pelanggaran atas ketentuan hukum yang prelaku.

Kondisi ideal tersebut belum sepenuhnya dilaksanakan oleh pelaku usaha, karena berbagai faktor terutama karena adanya unsur kelalaian yang mengakibatkan terancamnya perlindungan konsumen akibat mengkonsumsi suatu barang. Dengan demikian diperlukan upaya ekstra keras untuk meningkatkan perlindungan konsumen baik melalui sarana edukasi kepada konsumen dan pelaku usaha, maupun melalui upaya penegakan hukum oleh para penegak hukum.

Peneliti mengamati adanya dualisme dalam penerapan sanksi hukum terhadap pelanggaran pencantuman label pada barang. Pertama, jika ditinjau dari sisi kewajiban pelaku usaha, kelalaian pencantuman label pada barang hanya dikenakan sanksi administratif yaitu pencabutan perizinan dibidang perdagangan. Kedua, dari sudut pandang perlindungan konsumen, kelalaian tersebut dapat dikenakan sanksi pidana berupa pidana penjara paling lama 5 (lima) tahun atau pidana denda paling banyak Rp. 2.000.000.000,00 (dua miliar rupiah).

Peneliti juga melihat adanya pengabaian dua asas hukum yaitu asas Lex Posterior Derogat Legi Priori (undang-undang yang lebih baru mengenyampingkan undang- 
undang yang lama) dan asas Lex Superior Derogate Legi Inferiori (undang-undang yang lebih tinggi mengenyampingkan undang-undang yang lebih rendah tingkatannya). Permendag No. 73 Tahun 2015 menerapkan sanksi hukum berupa sanksi administratif, lebih ringan dari sanksi hukum berupa pidana penjara dan denda sebagaimana diatur dalam Undang-undang Perlindungan Konsumen dan Undang-undang Perdagangan.

Keberadaan hukum yang ideal atau setidak-tidaknya memuat prinsip keadilan sangat diperlukan dewasa ini. Hukum akan berfungsi sebagai pedoman bagi setiap orang untuk bertingkah laku yang akan memberikan kejelasan mengenai apa yang dapat diharapkan dari setiap tindakan yang dilkaukan oleh setiap orang. ${ }^{4}$

Hukum yang kuat akan mendukung program pembangunan nasional disegala bidang yang harus dilakukan secara berkesinambungan. Sasaran yang akan ditempuh dalam pembangunan hukum ialah terciptanya sistem hukum nasional yang adil, konsekuen dan tidak diskriminatif, dan terjaminnya konsistensi seluruh peraturan perundang-undangan pada tingkat pusat dan daerah, serta tidak bertentangan dengan peaturan dan perundang-undangan yang lebih tinggi, dan kelembagaan peradilan dan penegak hukum yang berwibawa, bersih, perofesional dalam upaya memulihkan kembali kepercayaan hukum masyarakat secara keseluruhan. Pembangunan hukum khususnya hukum ekonomi di Indonesia dimaksudkan agar bida digunakan sebagai fondasi dan pemandu para pelaku ekonomi untuk menjalankan aktivitasnya. ${ }^{5}$

Dari berbagai kondisi dan latar belakang yang diuraikan di atas, peneliti melihat adanya suatu permasalahan hukum yang timbul yaitu bagaimana pengaturan kewajiban

\footnotetext{
${ }^{4}$ Edi Setiadi dan Rena Yulia, Hukum Pidana Ekonomi, Yogjakarta: Graha Ilmu, 2010, Hlm. 1.

${ }^{5}$ Abdul Manan, Peranan Hukum Dalam Pembangunan Ekonomi, Jakarta: Kencana Pernada Media Group, 2014, Hlm. 24-36.
} 
pemasangan label dalam Bahasa Indonesia pada barang yang diproduksi di dalam negeri, berdasarkan peraturan perundang-undangan yang berlaku dan bagaimana meningkatkan kesadaran bagi konsumen dan pelaku usaha terkait kewajiban pencantuman label pada barang, untuk melindungi hak-hak konsumen untuk mendapatkan informasi lengkap mengenai barang yang dibelinya dan sekaligus meningkatkan pemahaman dan kesadaran bagi pelaku usaha atas kewajiban untuk mencantumkan label pada barang yang diproduksinya

\section{B. METODE PENELITIAN}

Penelitian hukum ini dilakukan melalui pendekatan yuridis (hukum) normatif, yang bersifat deskriptif analitis dan yang diteliti hanya bahan pustaka atau data sekunder. Penelitian hukum normatif ini data sekunder nya diperoleh melalui penelitian kepustakaan (library research). Penelitian hukum normatif biasanya merupakan studi dokumen/data tertulis (legal document) mempergunakan sumber-sumber data sekunder saja yang berupa peraturan perundang-undangan, teori hukum dan pendapat para sarjana. Penelitian deskriptif analisis digunakan untuk menjelaskan secara sistematis landasan hukum atau asas yang relevan terhadap fakta hukum yang dipertanyakan, serta menganalisis sendiri suatu peristiwa/kejadian untuk menjelaskan hubungan antara landasan hukum dengan fakta hukumnya, serta menunjukan kendala yang mungkin terjadi.

Penelitian ini adalah suatu kegiatan ilmiah yang berkaitan dengan analisa dan konstruksi, yang dilakukan secara metodologis, sistematis dan konsisten. Penelitian dalam bidang hukum, maka yang dilakukan menjadi lebih khusus yaitu penelitian hukum, yaitu penelitian yang didasarkan pada metode, sistematika dan pemikiran tertentu, yang 
bertujuan untuk mempelajari satu atau beberapa gejala hukum tertentu, dengan jalan menganalisanya.

Tujuan umum penelitian hukum (seperti halnya penelitian sosial lain) adalah untuk mendapatkan pengetahuan tentang gejala hukum sehingga dapat merumuskan masalah dan memperoleh pengetahuan yang lebih mendalam mengenai suatu gejala hukum, sehingga dapat merumuskan hipotesa. Sedangkan tujuan khusus dari suatu penelitian hukum adalah untuk mendapatkan asas-asas hukum, sistematika dari perangkat kaedah-kaedah hukum, taraf sinkronisasi vertikal dan horisontal, perbandingan hukum, sejarah hukum, identifikasi terhadap hukum tidak tertulis dan kebiasaan dan efektivitas hukum tertulis maupun hukum kebiasaan.

\section{Metode Pengumpulan Data}

Data dalam penelitian ini mempergunakan Data sekunder, yang diperoleh melalui studi pustaka / penelitian kepustakaan (library research), yaitu berupa

a. Bahan hukum primer, yaitu :

1) Undang-undang Nomor 7 Tahun 2014 tentang Perdagangan.

2) Undang-undang Nomor 20 Tahun 2014 tentang Standardisasi dan Penilaian Kesesuaian.

3) Undang-undang Nomor 8 Tahun 1999 tentang Perlindungan Konsumen

4) Peraturan Menteri Perdagangan Republik Indonesia Nomor 73/MDAG/PER/9/2015 tentang Kewajiban Pencantuman Label Dalam Bahasa Indonesia pada Barang.

5) Peraturan Menteri Perdagangan Republik Indonesia Nomor 67/MDAG/PER/11/2013. tentang Kewajiban Pencantuman Label Dalam Bahasa Indonesia pada Barang. 
b. Bahan hukum sekunder, yaitu buku teks, laporan penelitian, artikel ilmiah, makalah, jurnal, dan laporan penelitian.

c. Bahan hukum tersier. Bahan ini dijadikan sebagai pedoman untuk mengkaji bahan hukum primer dan bahan hukum sekunder, yang diperoleh dari kamus, bibliografi, dan ensiklopedi, antara lain Kamus Besar Bahasa Indonesia, Black's Law Dictionary Data yang diperlukan dalam penelitian dikumpulkan dengan beberapa alat pengumpulan data yaitu:

1. Studi dokumen atau bahan pustaka, yaitu suatu alat pengumpulan data yang dilakukan melalui data tertulis dengan mempergunakan "content analysis".

2. Pengamatan atau observasi.

Pengamatan dan wawancara dilaksanakan hanya jika diperlukan apabila suatu masalah yang diteliti perlu mendapatkan informasi, meminta masukan dan saran atau konfirmasi yang akurat untuk kepentingan penulisan proposal penelitian ini, dengan cara wawancara yang dilakukan adalah dengan teknik wawancara tidak berencana atau tidak berpatokan, artinya wawancara tidak terikat pada aturan-aturan yang ketat namun dengan persiapan yang matang. Dengan teknik wawancara ini pihak yang di wawancarai akan lebih terbuka dan tidak berpegang kepada daftar pertanyaan yang telah disiapkan seperti dalam wawancara berencana.

Penelitian ini dilakukan terhadap kaidah-kaidah hukum yang merupakan patokanpatokan berperilaku atau bersikap tidak pantas. Penelitian dapat dilakukan terhadap bahan hukum primer dan bahan hukum sekunder, sepanjang bahan-bahan tersebut mengandung kaidah-kaidah hukum. Asas merupakan dasar-dasar material atau sendisendi maupun arah bagi pembentukan kaidah hukum secara dinamis. Asas hukum 
membentuk isi kaidah hukum yang dibentuk atau dirumuskan oleh pihak-pihak yang berwenang melakukan kegiatan itu.

Penelitian asas-asas hukum ini harus dibedakan dengan penelitian terhadap asasasas perundang-undangan dan asas yurisprudensi. Asas perundang-undangan merupakan asas tentang berlakunya suatu undang-undang dalam arti material, seperti misalnya undang-undang tidak berlaku surut, undang-undang yang bersifat khusus menyampingkan undang-undang yang bersifat umum, dan lain-lain. Sedangkan asas yurisprudensi menyangkut soal peradilan di dalam praktek kenegaraan, seperti asas precedent, asas bebas, dan lain-lain.

Penelitian ini dilakukan terhadap pengertian dasar dalam sistem hukum, yang meliputi masyarakat hukum, subyek hukum, hak dan kewajiban, peristiwa hukum, hubungan hukum dan obyek hukum. Masyarakat hukum merupakan masyarakat sebagai sistem hubungan teratur dengan hukum sendiri. Subyek hukum adalah pihak-pihak yang menjadi pendukung hak dan kewajiban, di dalam hubungan teratur atau masyarakat hukum.

Hak merupakan peranan yang fakultatif oleh karena sifatnya, yakni boleh tidak dilaksanakan, peranan tersebut seringkali disebut kewenangan. Kewajiban atau tugas merupakan suatu peranan yang bersifat imperatif, oleh karena itu harus dilaksanakan. Peristiwa hukum adalah suatu keadaan (alamiah, kewajiban dan sosial), kejadian (kelahiran atau kematian seseorang) dan perilaku atau sikap tindak dalam hukum. Hubungan hukum merupakan hubungan-hubungan yang mempunyai akibat hukum. Obyek hukum pada dasarnya merupakan suatu kepentingan yang menjadi obyek hubungan-hubungan hukum yang dilakukan oleh subyek hukum. 
Tujuan penelitian ini adalah untuk mengungkapkan kenyataan sampai sejauh mana perundang-undangan tertentu serasi secara vertikal atau mempunyai keserasian secara horisontal apabila menyangkut perundang-undangan yang sederajat mengenai bidang yang sama.

\section{PEMBAHASAN}

Konsumen adalah salah satu faktor terpenting dalam kegiatan perekonomin. Seperti diketahui dalam kegiatan perekonomian dikenal tiga kegiatan utama yaitu di bidang produksi, distribusi dan konsumsi. Produksi merupakan kegiatan untuk menambah faedah (kegunaan) suatu benda atau menciptakan benda baru sehingga lebih bermanfaat dalam memenuhi kebutuhan. Distribusi adalah suatu proses penyampaian barang atau jasa dari produsen ke konsumen dan para pemakai, pada waktu dan dimana barang atau jasa tersebut diperlukan, sedangkan konsumsi adalah adalah tindakan menghabiskan atau mengurangi secara berangsur-angsur manfaat suatu barang dalam memenuhi kebutuhan untuk memelihara kelangsungan hidupnya.

Secara sederhana dapat digambarkan siklus hidup suatu barang mulai dari tahap pembuatan / produksi oleh perusahaan atau pabrik pembuatnya (sering disebut juga Produsen). Produsen harus menjual barang produksinya yang hasil penjualannya akan menjadi pendapatan (revenue) yang setelah dikurangi dengan biaya-biaya akan menjadi keuntungan (profit). Untuk mendapatkan profit ini produsen menjual produknya ke konsumen melalui distributor. Distributor akan mengambil keuntungan dari selisih harga jual ke konsumen dengan harga beli dari Produsen.

Konsumsi adalah tahapan terakhir dan paling penting karena ditahap ini barang produksi akan disukai dan selanjutnya dibeli konsumen atau sebaliknya barang tersebut 
menjadi stok (inventory) di gudang toko karena tidak diminati konsumen. Semakin banyak barang dibeli konsumen maka produsen akan mendapatkan semakin besar keuntungan. Dan sebaliknya, jika konsumen tidak meminati barang yang ditawarkan, maka sudah terbayang jelas kerugian yang akan diderita produsen.

Untuk menarik minat konsumen sekaligus membentuk loyalitas konsumen atas produk-produk yang dibuat oleh Produsen, diperlukan banyak biaya dan upaya yang harus dilakukan oleh Produsen dan distributornya. Apalagi dalam situasi persaingan ketat akibat banyaknya kompetitor yang memproduksi barang yang sama menyebabkan para produsen berlomba-lomba membuat dan menciptakan program pemasaran yang sesuai dengan kelas sosial dan karakteristik konsumen. Situasi ini diperburuk dengan kondisi pertumbukan ekonomi yang masih berat pada tahun 2019 lalu dan akan tetap demikian di tahun 2020 ini.

Perlambatan ekonomi dan dinamika ekonomi global yang semakin memburuk menyebabkan pelaku usaha harus kreatif dan mengerahkan segala daya dan upaya mencari cara dan strategi untuk menarik perhatian konsumen. Pelaku usaha berupaya menyiasati pelemahan pertumbuhan ekonomi tersebut dengan berbagai cara, antara lain dengan cara mengurangi atau menekan biaya / pengeluaran perusahaan (cost reduction program) termasuk biaya promosi / iklan, atau dengan menggunakan sarana digitalisasi dan otomasi dan mempergunakan konsep IOT (Internef of Things), yang diimplementasikan dengan cara perdagangan secara elektronik (e-commerce).

Aksi korporasi (corporate action) tersebut mau tidak mau harus dilakukan korporasi jika tidak ingin terdesrupsi dengan sendirinya atau oleh kompetitor mengingat persaingan saat ini begitu ketat dan sengitnya sehingga korporasi yang dapat bertahan 
adalah korporasi yang dapat beradaptasi dengan baik dengan kondisi saat ini. Banyak korporasi yang ditinggalkan oleh konsumennya karena produk dan cara perdagangannya tidak sesuai dengan keinginan konsumen.

Namun aksi korporasi ini juga membawa dampak negatif apabila dilakukan tidak sesuai dengan ketentuan yang berlaku, antara lain dengan mencantumkan label pada barang yang diproduksi, yang berisi deskripsi lengkap barang yang dijual. Ketidaktaatan pelaku usaha melaksanakan kewajiban ini akan menjadikan konsumen sebagai pihak yang rentan menjadi korban.

\section{Kewajiban Pencantuman Label Berbahasa Indonesia}

Ungkapan bahwa pembeli adalah raja, adalah suatu frasa yang menggambarkan begitu pentingnya peran konsumen bagi pelaku usaha sehingga konsumen harus selalu diberikan pelayanan yang terbaik.Ungkapan ini juga untuk mengingatkan akan hak konsumen dalam mendapatkan barang yang berkualitas sesuai dengan kondisi dan jaminan yang dijanjikan. Konsumen juga berhak untuk mendapatkan informasi yang benar, jelas, dan jujur guna mengetahui apa saja informasi terkait produk yang dibelinya. ${ }^{6}$

Saat ini terjadi perubahan tren atau kecenderungan belanja konsumen ke belanja online, yang saat ini sudah menjadi gaya hidup masyarakat tidak hanya di dunia tetapi juga melanda Indonesia. Lembaga Nielsen Indonesia mengatakan konsumen di seluruh dunia menunjukkan adanya permintaan yang terus meningkat untuk solusi nyaman yang

\footnotetext{
${ }^{6}$ Berdasarkan Pasal 4 Undang-undang Nomor 8 Tahun 1999 tentang Perlindungan Konsumen, Hak Konsumen, antara lain adalah :

1) Hak atas kenyamanan, keamanan, dan keselamatan dalam mengkosumsi barang dan/atau jasa;

2) hak untuk memilih barang dan/atau jasa serta mendapatkan barang dan/atau jasa tersebut sesuai dengan nilai tukar dan kondisi serta jaminan yang dijanjikan;

3) hak atas informasi yang benar, jelas, dan jujur mengenai kondisi dan jaminan barang dan/atau jasa, dan lain-lain.
} 
dapat membantu menyederhanakan hidup mereka, dan hal ini sangat mempengaruhi kebiasaan konsumsi dan belanja mereka.

Menurut Nielsen Indonesia, belanja online di dominasi oleh pembelian elektronik sebesar 35\%, travel 27\%, fashion 16\%, IT \& Mobile 13\%, kosmetik 4\%, buku 2\% dan lain-lain. Selain belanja online, sebagian konsumen juga tetap melakukan belanja offline dengan mendatangi langsung toko-toko penjualan barang. Keuntungan dari belanja offline ini adalah konsumen dapat secara langsung melihat, mencoba, membandingkan dan berdiskusi langsung dengan penjual. Dengan cara ini, resiko konsumen mendapat barang yang tidak sesuai dengan yang diinginkan relatif kecil dan dalam hal terjadi kerusakan pada barang yang dibeli, konsumen dapat langsung mengembalikan ke toko penjualnya.

Apapun jenis belanja yang dilakukan oleh konsumen, baik online maupun offline, hak-hak konsumen harus tetap diperhatikan karena konsumen adalah pemilik uang yang memiliki daya beli tinggi dan dapat memilih barang apa yang akan dibeli sesuai dengan yang dikehandaki konsumen. Sehingga konsumen harus didudukan pada posisi sebagai subyek jual beli bukan obyek jual beli, dimana produsen selalu mencoba memaksakan tren penjualan suatu barang agar terbentuk suatu positioning dimata konsumen atas barang yang dijual produsen tersebut. Dalam situasi ini, jelas konsumen diletakkan sebagai obyek sedangkan produsen adalah subyeknya, dimana produsen seringkali melalaikan kewajibannya selaku pelaku usaha sebagaimana diamanatkan oleh Undangundang Nomor 8 Tahun 1999 tentang Perlindungan Konsumen. ${ }^{7}$

\footnotetext{
${ }^{7}$ Berdasarkan Pasal 4 Undang-Undang Nomor 8 Tahun 1999 tentang Perlindungan Konsumen, kewajiban pelaku usaha, antara lain adalah :

1) beritikad baik dalam melakukan kegiatan usahanya;
} 
Karena pentingnya kedudukan konsumen, pemerintah Republik Indonesia menegaskan dalam undang-undang yang sangat melindungi hak-hak konsumen dan mengharapkan produsen untuk senantiasa mentaati norma-norma hukum yang diatur di dalamnya yaitu Undang-undang Nomor 8 Tahun 1999 tentang Perlindungan Konsumen. Undang-undang ini menekankan pentingnya perlindungan konsumen karena semakin terbukanya pasar nasional sebagai akibat dari proses globalisasi ekonomi harus tetap menjamin peningkatan kesejahteraan masyarakat serta kepastian atas mutu, jumlah, dan keamanan barang dan/atau jasa yang diperolehnya di pasar, sebagaimana dimaksud dalam butir c bagian pertimbangan UU Perlindungan Konsumen.

Perlindungan konsumen ditegaskan kembali pada pasal 8 ayat (1) butir i UU Perlindungan Konsumen yang selengkapnya berbunyi : Pelaku usaha dilarang memproduksi dan/atau memperdagangkan barang dan/atau jasa yang tidak memasang label atau membuat penjelasan barang yang memuat nama barang, ukuran, berat/isi bersih atau netto, komposisi, aturan pakai, tanggal pembuatan, akibat sampingan, nama dan alamat pelaku usaha serta keterangan lain untuk penggunaan yang menurut ketentuan harus dipasang/dibuat;

Kewajiban mencantumkan label pada barang yang diproduksi diatur lebih terinci dalam Peraturan Menteri Perdagangan Nomor 73/M-DAG/PER/9/2015 tentang kewajiban pencantuman label dalam Bahasa Indonesia pada barang. Dalam Permendag Nomor 73 tahun 2015 ini, yang dimaksud dengan label adalah setiap keterangan mengenai Barang yang berbentuk tulisan, kombinasi gambar dan tulisan, atau bentuk lain

2) memberikan informasi yang benar, jelas dan jujur mengenai kondisi dan jaminan barang dan/atau jasa serta memberi penjelasan penggunaan, perbaikan dan pemeliharan;

3) memperlakukan atau melayani konsumen secara benar dan jujur serta tidak diskriminatif, dan lain-lain 
yang memuat informasi tentang Barang dan keterangan Pelaku Usaha, serta informasi lainnya yang disertakan pada Barang, dimasukkan ke dalam, ditempelkan/melekat pada Barang, tercetak pada Barang, dan/atau merupakan bagian Kemasan Barang.

\section{Hak Konsumen Mendapatkan Informasi atas Barang}

Label bukan sekedar formalitas berisi keterangan yang ditempelkan, disisipkan atau menjadi bagian dari suatu produk. Label merupakan salah satu bentuk informasi bagi konsumen mengenai suatu barang/jasa sebagaimana diatur dalam UU Perlindungan Konsumen. Konsumen berhak memperoleh informasi yang benar, jelas, dan jujur mengenai kondisi dan jaminan barang dan/atau jasa. Pemberian informasi ini juga menunjukkan hak-hak konsumen lainnya yakni hak atas kenyamanan, keamanan, dan keselamatan dalam mengkomsumsi barang dan/atau jasa, serta hak konsumen untuk memilih barang dan/atau jasa.

Pencantuman Label dapat berupa: a. embos atau tercetak; b. ditempel atau melekat secara utuh; atau c. disertakan atau dimasukkan ke dalam Barang dan/atau Kemasan. Besarnya Label yang ditempel atau melekat secara utuh disesuaikan dengan ukuran Barang atau Kemasan secara proporsional. Keterangan atau penjelasan Label yang terkait dengan keselamatan, keamanan, dan kesehatan Konsumen serta lingkungan hidup, harus memuat: a. cara penggunaan; dan b. simbol bahaya dan/atau tanda peringatan yang jelas dan mudah dimengerti. Keterangan mengenai identitas Pelaku Usaha paling sedikit memuat: a. nama dan alamat produsen untuk Barang produksi dalam negeri; $b$. nama dan alamat importir untuk Barang asal Impor; atau c. nama dan alamat Pedagang Pengumpul jika memperoleh dan memperdagangkan Barang hasil produksi Pelaku Usaha 
Mikro dan Pelaku Usaha Kecil. Pelaku Usaha wajib mencantumkan keterangan atau penjelasan yang menurut ketentuan peraturan perundang undangan harus dicantumkan. Untuk Barang yang telah diberlakukan SNI secara wajib, pencantuman Label dalam Bahasa Indonesia mengikuti penandaan yang ditetapkan dalam SNI. Terakhir, Pelaku Usaha dilarang mencantumkan Label dalam Bahasa Indonesia yang memuat informasi: a. secara tidak lengkap; dan/atau b. tidak benar dan/atau menyesatkan Konsumen.

\section{PENUTUP}

\section{Kesimpulan}

Pengaturan kewajiban pemasangan label dalam Bahasa Indonesia pada barang yang diproduksi di dalam negeri antara lain untuk memastikan pemenuhan hak-hak konsumen dan kewajiban pelaku usaha, yaitu 1) hak konsumen atas kenyamanan, keamanan, dan keselamatan dalam mengkosumsi barang dan/atau jasa, 2) hak atas informasi yang benar, jelas, dan jujur mengenai kondisi dan jaminan barang dan/atau jasa; Atas hak-hak konsumen tersebut, pelaku usaha berkewajiban untuk memberikan informasi yang benar, jelas dan jujur mengenai kondisi dan jaminan barang dan/atau jasa serta memberi penjelasan penggunaan, perbaikan dan pemeliharan. Pelaku usaha juga dilarang untuk memproduksi dan/atau memperdagangkan barang dan/atau jasa yang : 1) tidak memenuhi atau tidak sesuai dengan standar yang dipersyaratkan dan ketentuan peraturan perundang-undangan, 2) tidak memasang label atau membuat penjelasan barang yang memuat nama barang, ukuran, berat/isi bersih atau netto, komposisi, aturan pakai, tanggal pembuatan, akibat sampingan, nama dan alamat pelaku usaha serta keterangan lain untuk penggunaan yang menurut ketentuan harus dipasang/dibuat dan 3) tidak mencantumkan informasi dan/atau petunjuk penggunaan barang dalam bahasa 
Indonesia sesuai dengan ketentuan perundang-undangan yang berlaku. Hak dan kewajiban konsumen dan pelaku usaha ini diatur secara lengkap dan jelas dalam : 1) Undang-undang Nomor 7 Tahun 2014 tentang Perdagangan, 2) Undang-undang Nomor 20 Tahun 2014 tentang Standardisasi dan Penilaian Kesesuaian 3) Undang-undang Nomor 8 Tahun 1999 tentang Perlindungan Konsumen, 4) Peraturan Menteri Perdagangan Republik Indonesia Nomor 73/M-DAG/PER/9/2015 tentang Kewajiban Pencantuman Label Dalam Bahasa Indonesia pada Barang dan 5) Peraturan Menteri Perdagangan Republik Indonesia Nomor 67/M-DAG/PER/11/2013. tentang Kewajiban Pencantuman Label Dalam Bahasa Indonesia pada Barang.

Baik konsumen maupun pelaku usaha harus menyadari peran masing-masing sesuai dengan posisi / kedudukannya baik selaku pembeli dan penjual produk/barang. Pada masing-masing kedudukan ini melekat hak dan kewajiban konsumen maupun pelaku usaha, yang menjadikan masing-masing pihak memiliki kedudukan seimbang dalam suatu transaksi jual beli barang / produk. Oleh karena itu konsumen sebagai pihak pembeli (pemilik uang) harus senantiasa meningkatkan kemampuannya selaku konsumen yang mandiri / independen, yang keputusannya tidak dapat dipaksakan oleh pelaku usaha / penjual barang. Demikian juga pelaku usaha, harus senantiasa meningkatkan pelayanannya kepada masyarakat / konsumen pembeli produk, agar setiap barang yang diproduksinya senantiasa memperhatikan kepentingan konsumen dan bukan semata untuk meningkatkan keuntungan semata.

\section{Saran}

Untuk lebih mengoptimalkan peran konsumen selaku pihak yang memiliki peran utama dalam perputaran roda ekonomi bangsa, maka diperlukan peran dan kehadiran 
pemerintah Indonesia untuk senantiasa meningkatkan kesadaran konsumen atas hakhaknya ini melalui berbagai sarana formal maupun informal. Pendidikan formal harus sudah dimulai sejak dini kepada anak-anak melalui pelajaran-pelajaran di sekolah atau kampus. Dengan pendidikan formal ini diharapkan anak-anak akan memahami dan mengimplementasikan pengetahuan yang diperolehnya dalam kehidupan sehari-hari dan apabila nantinya anak-anak tersebut tumbuh dan berkembang menjadi seorang pemimpin dunia usaha, maka kesadaran dalam berperilaku usaha sudah tertanam dalam dirinya. Dari sisi informal dapat dilakukan melalui sosialisasi dan penyuluhan hukum kepada seluruh lapisan masyarakat, yang melibatkan akademisi / universitas dalam melaksanakan tridharma perguruan tinggi.

\section{DAFTAR PUSTAKA}

\section{Peraturan Perundang-undangan:}

Republik Indonesia. Undang-undang Nomor 7 Tahun 2014 tentang Perdagangan. . Undang-undang Nomor 20 Tahun 2014 tentang Standardisasi dan Penilaian Kesesuaian. . Undang-undang Nomor 8 Tahun 1999 tentang Perlindungan Konsumen - Peraturan Menteri Perdagangan Republik Indonesia Nomor 73/MDAG/PER/9/2015 tentang Kewajiban Pencantuman Label Dalam Bahasa Indonesia pada Barang.

- Peraturan Menteri Perdagangan Republik Indonesia Nomor 67/MDAG/PER/11/2013. tentang Kewajiban Pencantuman Label Dalam Bahasa Indonesia pada Barang.

\section{Buku:}

Assegaf, Ahmad Fikri. Penjelasan Hukum tentang Klausula Baku. Jakarta: Pusat Studi Hukum dan Kebijakan Indonesia, 2014.

Darmodiharjo, Darji dan Shidarta, Pokok-pokok filasafat hukum, apa dan bagaimana filsafat hukum Indonesia. Jakarta: PT. Gramedia Pustaka Utama, 2006

Huijbers, Theo, Filsafat Hukum dalam Lintasan Sejarah. Yogyakarta: Penerbit Kanisius, 1982. 
Keraf, Sonny. Etika Bisnis, Tuntutan dan Relevansinya.Yogyakarta: Penerbit Kanisius, 1998.

Manan, Abdul, Peranan Hukum Dalam Pembangunan Ekonomi. Jakarta: Kencana Pernada Media Group, 2014.

Setiadi, Edi dan Rena Yulia. Hukum Pidana Ekonomi. Yogjakarta: Graha Ilmu, 2010.

Shofie, Yusuf, Tanggung Jawab Pidana Korporasi dalam Hukum Perlindungan Konsumen di Indonesia. Bandung : PT Citra Aditya Bakti, 2011.

Jurnal Ilmiah, Artikel, Majalah:

Anwar C. "Problematika mewujudkan keadilan substantive dalam penegakan hukum di Indonesia”. Jurnal pada majalah Jurnal Konstitusi Mahkamah Konstitusi Republik Indonesia Volume III Nomor 1, Juni 2010.

\section{Internet:}

Bappenas. "Perdagangan”. https://www.bappenas.go.id/diakses 23 November 2019

Tobing, Sorta. "Sektor Industri Masih Penyumbang Terbesar Pertumbuhan Ekonomi". https://katadata.co.id/ diakses 23 November 2019

Wikipedia. "Jalur Sutra". https://id.wikipedia.org/wiki/diakses 23 November 2019 